\title{
Conditions for the Creation of the "Network of the Most Interesting Villages". Results of Expert Evaluation of 50 Polish Villages
}

\author{
Marcin WóJCIK, Lódź*
}

with 6 figures and 2 tables in the text

\section{Content}

Summary 67

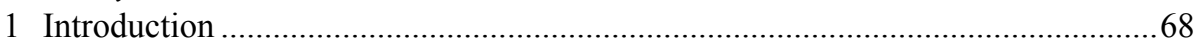

2 General conditions of rural renewal in Poland ....................................................69

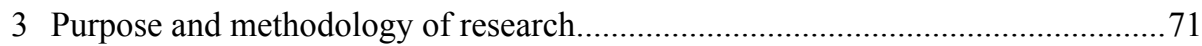

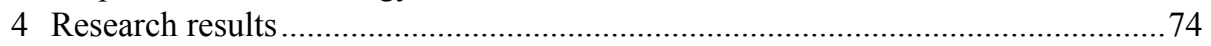

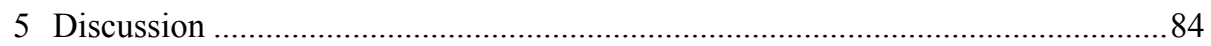

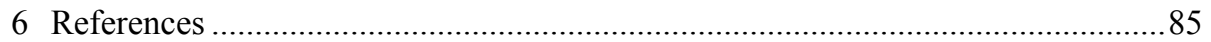

\section{Summary}

The aim of the study is to interpret the results of the expert evaluation of 50 Polish villages with considerable cultural value. The evaluation of this group of villages was meant to determine the possibility of creating a Network of the Most Interesting Villages in Poland. The article presents the methodological basis of the evaluation, as well as the diversity in the group of villages in selected traits. The aim of the emerging Network of the Most Interesting Villages is to create a brand tourist product in rural areas. The creation of the Network is a long-term process accompanied by numerous goals in various aspects of functioning of villages. The new product is operated by the Polish Network for Rural Renewal and Development (PSORW) - an association of approxamitely 50 entities, mostly local governments. The spatial distribution of the 50 villages selected for the project has shown that the greatest resources of material

* Marcin WóscıK, PhD., Department of Regional and Social Geography, Faculty of Geographical Sciences, University of Łódź, Kopcińskiego St. 31, 90-142 Łódź, Poland; email: marcin.wojcik@geo.uni.lodz.pl 
cultural heritage can be found in regions with predominant fixed residential and farming buildings (brick, stone, and daub) before World War II, i.e. in the areas joined by Poland in 1945 (Western Pomerania [województwo zachodniopomorskie], Lower Silesia [województwo dolnośląskie], Warmia-Masuria [województwo warmińsko-mazurskie]). The condition of the original spatial and physiognomic systems depended largely on the intensity of post-war transformation of rural settlements under the influence of industrialisation and urbanisation. Quite a lot of interesting villages can be found in the rural area of Podlasie [województwo podlaskie], Lublin [województwo lubelskie], Lesser Poland [Matopolska] and in the Subcarpathian Voivodship [województwo podkarpackie]. The best-rated aspects include: nature and landscape inside a village; village's characteristic features; access roads; historic buildings; natural and landscape surroundings; rural layout. The worst-rated aspects in the evaluation included: the character and condition of fences; technical condition of buildings; services, products, souvenirs; route information system; places for tourists; visual information system.

\section{Introduction}

The problem of rural renewal has been present in the European literature since the 1970s, when researchers from various countries began to ponder the possibilities of revitalising settlement structures combined with activities aimed at improving the quality of life, including environmental values (see HenKel 2004, pp. 311-312; Ministerium für Umwelt, Raumordnung und Landwirtschaft des Landes NordrheinWeSTFALEN 1998). Western European countries, in which the processes of rural renewal stemmed from the search for tools to weaken or reverse the processes of depopulation and regression of economic activity, are especially experienced in this regard. An attempt at improving the quality of life and its dominant position in rural development were the biggest asset in building the positive image of rural areas. Rural renewal, e.g., in the German model of transformation was additionally strongly focused on the historical heritage of rural settlements and the relations between local communities and their natural surroundings (see GRABSKI 1989; LIENAU 1989). One important factor in European rural renewal was also the need to prevent uncontrolled development of rural construction, especially in metropolitan areas (GILG 1998; Woods 2005). The use of numerous communication methods in creating local rural development strategies, and thus the emphasis on the subjective character of local community in the renewal process, was also an interesting aspect (see HeINRITZ \& WiesSNER 1997).

Rural renewal in Western European countries was and is multidimensional, and included numerous planning (revitalisation), social and infrastructural goals (see PlanCK 1986; MillendORFER 1990). In the summary of his discussion on the effects of rural renewal policies in Germany, G. HENKEL (2004, pp. 319-320) gives the priorities 
that should determine activities surrounding the idea of rural development. These thoughts can be ordered according to the following principles:

- building the image of rural areas, especially the care for good technical condition of buildings and their aesthetic aspect;

- development of central areas by designing or recreating public spaces, with consideration to their service (central) functions;

- involvement of many actors of local development in the process of rural renewal, namely local communities, local authorities, entrepreneurs and nongovernmental organisations;

- stabilisation of the vision of rural development, which should be rooted in the tradition of development and adapted to regional projects on one hand, and based on a clear strategy of transformation (the conservative character of rural development) on the other.

The long tradition of rural renewal programmes resulted in many countries in the ability to create networks of "the most beautiful villages", serving as representations of the best examples of local development based on revitalisation and rural gentrification (e.g. France, Italy, Germany, Belgium). In 2014, an idea emerged in Poland to create a network of villages, whose cultural heritage, combined with renewal processes, would serve as the foundation for building a tourist brand dubbed "The Network of the Most Interesting Villages". The study results presented in this paper show the first stage of this work, related to the inventorying of selected villages and determining their chances of being included in the network.

\section{General conditions of rural renewal in Poland}

There are currently many scientific studies on the transformation of Polish countryside, which is undoubtedly related to the improvement of the socio-economic situation of many rural areas after Polish accession to the European Union. The launch of rural development programmes successfully activates the processes of modernisation in agriculture, farming and food industry, strengthens entrepreneurship, as well as various activities of local communities. There are significant developmental inequalities in this regard, both on regional and local levels (see RUDNICKI 2010; BicZKOWSKI 2013). We should keep in mind, that the European funds are one of many factors that influence local developmental processes, while social capital, meaning the ability of territorial communities to self-organise and co-operate is one of the key factors. This social capital affects the transformations of socio-economic structures, including the organisation of settlement systems (KRETEK-KAMIŃSKA et al. 2014; WósciK 2012). 
One of the problems of rural transition is the transformation of the cultural landscape, especially in terms of its functional, utilitarian, as well as aesthetic and physiognomic coherence. Difficulties in correct formation of rural landscapes depend on numerous factors, one of the most significant being the mentality of the inhabitants inherited from the previous socio-economic system and its developmental ideology (Socialist modernisation). For many decades, 'rusticity' was something to be ashamed of, criticised by the ideologues of social modernisation of the time, which was based on the primacy of heavy industry, collectivism and urbanisation (see BUKRABA-RYLSKA 1992; WóJCIK 2012; NiEdźWIEDZKA-FILIPIAK; WILCZYŃSKI 2015). The regional character of rural space was mindlessly destroyed in different ways, which was evident not only in the attempts to dissolve social ties and weaken cultural identity, but also in promoting the model of spatial development that involved a departure from architectural regionalism in favour of simplistic designs that were put everywhere, regardless of the natural and cultural environment. The rural architectural and physiognomic transformations, the degradation of valuable objects of noble and peasant cultural heritage, as well as national and religious minorities have led to great devastation of landscape. We have largely lost what can be called the complex nature of rural cultural heritage, i.e. an integral coexistence in various places (villages, cultural regions) of different types of valuable objects, i.e. religious, residential, housing, farming, infrastructural, along with the whole social content created by 'long-lasting' institutions and the people who are aware of these cultural values (NIEDŹwIEDZKA-FILIPIAK 2009; WóJCIK 2012).

In contemporary circumstances, rural renewal, especially in the context of certain projects funded by the European Union (EU), is a very wide concept, encompassing the revitalisation of various objects, improvement of aesthetics and development of public space, investments in infrastructure, the strengthening of social capital and local identity, i.e. cuisine, cultural activities, education, etc. (see KŁODZIŃSKI et al. 2007; WóJCIK 2010; WILCZYŃSKi 2012a; IDZIAK \& WILCZYŃSKi 2013). One of the weakest points in the objective and realistic assessment of the cultural value of rural areas is the lack of comprehensive knowledge about their scope, both quantitative and qualitative. This knowledge is fragmented both in territorial and institutional terms. In territorial terms, villages with more intense tourist traffic (guidebooks, maps, internet sources, discussion forums, etc.) and concentration of significant historic value (tourist regions and 'strong' cultural regions of various types - historical, ethnographic) are better described. In the institutional dimension, the fragmentation mostly involves the incoherence of knowledge owned by institutions tasked with archiving such data (e.g. conservation, local government, scientific and research units), especially where it relates to spatial location and various short-distance interrelations (spatial, functional, social).

Attempts to inventory and assess the preserved cultural heritage in rural areas, particularly peripheral ones, requires knowledge from many sources, especially considering the fact that the information contained in the records are in many cases obsolete, mainly due to the contemporary processes of destruction of objects with 
significant historical-cultural value, especially those in private hands (mostly historic farm buildings). One chance to reverse these negative trends is to take institutional actions that expand beyond the range of actions taken by local leaders interested in creative development of cultural heritage, that take the form of a network - a group connected by shared goal, organisational foundation, principles and development plans, with central organs to create regulations in this regard.

\section{Purpose and methodology of research}

The aim of the study is to interpret the results of the expert evaluation 50 Polish villages with high concentration of cultural values - material, institutional and spiritual. The evaluation of this group of villages was meant to determine the possibility of creating a Network of the Most Interesting Villages. The article presents the scope for the evaluation, the diversity of the group of villages in selected regards, as well as the main problems of protecting and shaping valuable rural heritage. ${ }^{1}$

The aim of the emerging Network of the Most Interesting Villages is to create a brand tourist product in rural areas. The experiences of rural renewal programme in the Opole Voivodship [województwo opolskie] that has been operating for over 15 years served as a basis for creating a factual concept and organisational foundation for a nation-wide network of villages, whose values may interest tourist from Poland and other countries (see IDZIAK \& WILCZYŃSKI 2013). The original idea of a network of interesting villages was born in France and found many followers, mainly in the European Union, as well as in Canada and Japan (see WILCZYŃSKi 2012b). The primary development goal in all cases is to counteract the negative demographic and economic processes, such as depopulation, loss of economic activity, decreasing property value, loss of cultural advantages, etc. A specific feature of the Polish project is that it shifts focus from 'most beautiful' to 'most interesting', which is on one hand related to considerable degradation of material heritage in the whole country, as well as the emphasis on the role of various socio-economic processes that now lead to the increasing significance of rural areas and their supra-local influence. Such network is an opportunity to cultivate rurality and preserve the cultural heritage, as well as for a village to have a chance of developing and improve its inhabitants' quality of life (IDZIAK \& WiLCZYŃSKi 2013; NiedźWIEDZKA-FILIPIAK \& WilCZYŃSKi 2015).

The creation of the Network is a long-term process accompanied by numerous goals in various aspects of functioning of villages. The new product is operated by

1 The project „Creation the Network of the Most Interesting Villages“ was commissioned by the Foundation of Assistance Programmes for Agriculture (FAPA), subordinate to the Ministry of Agriculture and Rural Development in the period between January $1^{\text {st }}$ and May $31^{\text {st }}, 2015$. Leaders of team research: Ryszard WILCZYŃSKI (initiator), Marcin WóJCIK (team principal investigator). 
the Polish Network for Rural Renewal and Development (PSORW) - an association of approximately 50 entities, mostly local governments, whose aim is to exchange experiences, knowledge and best practices in the field of socio-economic development of rural areas. The activities of these self-governments were crucial for institutionalising the creation of the Network of the most Interesting Village and thus triggering the mechanism of nominating candidates, developing of the operation principles, as well as the emergence of a group of elite villages. The idea born during the first years of Poland as a member of the EU should be completed by 2017, when the network starts to really function on the basis of uniform principles of the action plan, creating the image, and tourism brand.

Figure 1: Distribution of the villages submitted (100) and evaluated (50) in the period between January and May 2015

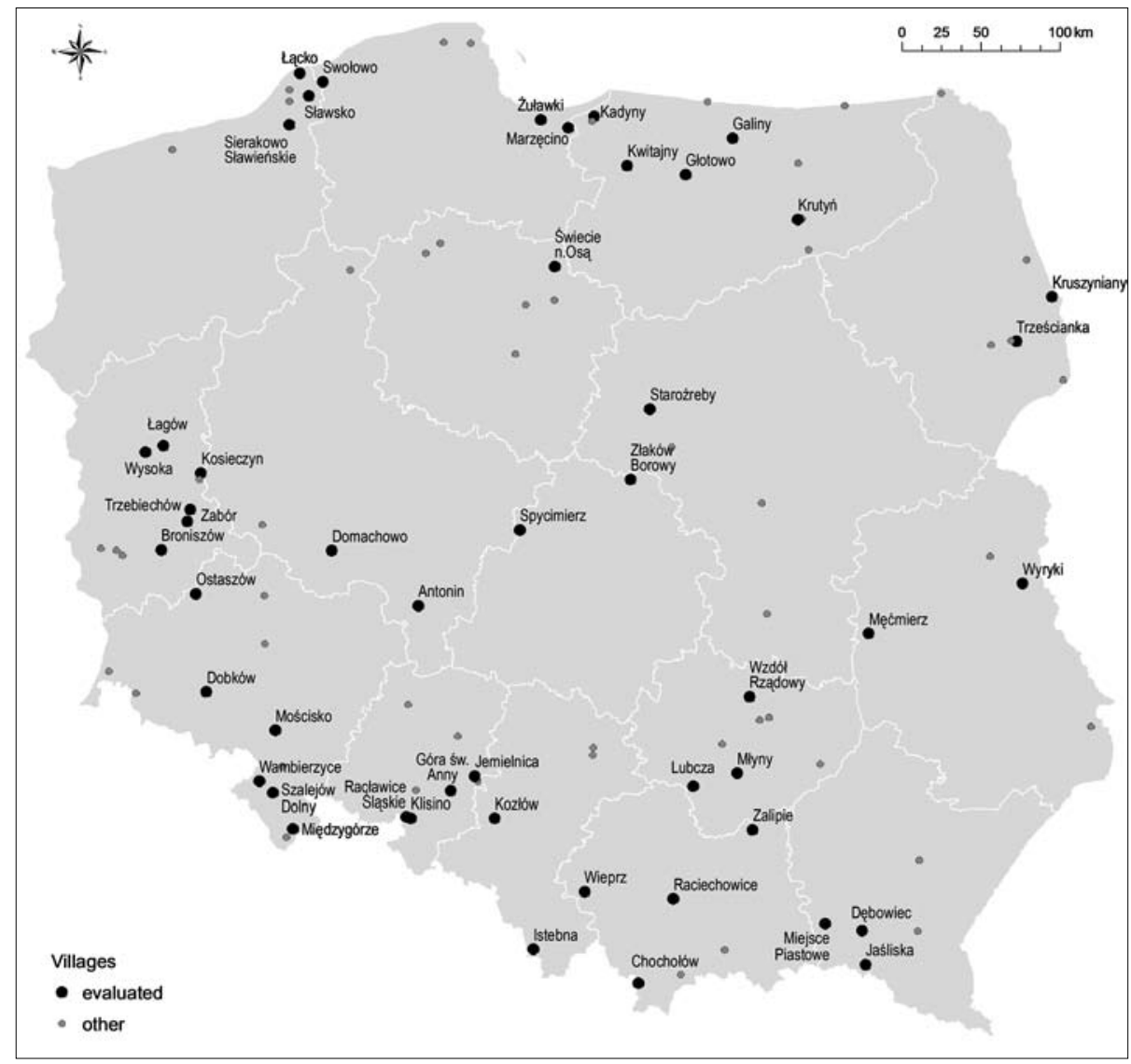

Source: own study 
In 2015, the operations of PSORW concentrated on the implementation of the Network project, mainly on the evaluation of the cultural values of the first 50 villages in a list of 100 chosen by the members of the association based on their own information, as well as the information provided by restorers and regional government institutions (Fig. 1). The project was implemented by the Rural Development Programme (20072013) commissioned by the Foundation of Assistance Programmes for Agriculture, subordinate to the Ministry of Agriculture and Rural Development in the period 0105.2015. The selection of 50 villages from the list of 100 was made by the scientific leader of the project based on the preliminary assessment of all settlement units in three scopes, i.e. the preservation of the historic spatial layout and the degree of its contemporary transformation, social activity and natural and anthropogenic values in vicinity. One of the principles was to invite villages from each region in Poland into the project (at least one village from each region in the project).

Location of villages in the list received from FAPA is mostly a function of the state of preservation of the cultural heritage, especially the material one, of Polish villages. The spatial location of the 50 villages selected for the project largely coincided with the distribution of all villages in the list. The number of villages was also influenced by the involvement of local governments and preservation institutions in the project. Large interest in the project could be seen in Lubusz [województwo lubuskie], Opole [województwo opolskie], Lower Silesia [województwo dolnośląskie], Warmia-Masuria [województwo warmińsko-mazurskie] voivodships.

The spatial location of the villages in Poland has shown that the greatest resources of material cultural heritage can be found in regions with predominant fixed residential and farming buildings (brick, stone, wattle and daub) before World War II, i.e. in the areas joined by Poland in 1945 (Western Pomerania [województwo zachodnio-pomorskie], Lubusz, Lower Silesia, Opole, Warmia-Masuria voivodships). The condition of the original spatial and physiognomic systems depended largely on the intensity of post-war transformation of rural settlements under the influence of industrialisation and urbanisation. Quite a lot of interesting villages can be found in the rural area of Podlasie [województwo podlaskie], Lublin [województwo lubelskie], Lesser Poland [Małopołska] and the Subcarpathian Voivodship [wojewódtzwo podkarpackie]. On the other hand, irreversible damage occurred in the central regions, i.e. in the Łódź [województwo łódzkie], Masovia [województwo mazowieckie], Holy Cross [województwo świętokrzyskie] and Kuyavian-Pomerania [województwo kujawsko-pomorskie] voivodships, where the wooden buildings were replaced by brick ones and the process lacked any reflection about the historical value of rural layouts. Consequently, the rural material cultural heritage in central Poland can exclusively be seen in open-air museums.

Assessment of the potential of rural areas is based on a multi-criteria method, fieldwork and lab work, which is based on the evaluation sheet, or Village Evaluation 
Form. Its shape is the result of many years of attempts to develop able to assess the rural cultural resources in many aspects (see NiEDźWIEDZKA-FILIPIAK \& WILCZYŃSKI 2015, pp. 98-100). The idea of identifying the cultural resources of interesting villages refers to the division of villages into two types, i.e. cultural heritage villages with relatively high historical value, especially as far as architecture and physiognomy are concerned, and the experience and emotion villages that may be attractive due to their specific features or accommodation offer. In this concept, the relationship between the creation of a brand and the execution of the revitalisation paradigm, including the internal development of a village, is especially important (see NIEDźWIEDZKA-FILIPIAK \& WILCZYŃSKI 2015).

The evaluation is based on criteria that encompass three main 'value issues', i.e. resources, specificity and impressions (see NIEDŹWIEDZKA-FILIPIAK \& WILCZYŃSKI 2015 and Table 1). Their joint consideration determines the total evaluation of a given village's quality and offer, which in turn contributes to consumer satisfaction, who experiences certain emotional states during their stay. The concept of network formation assumes that cognitive values are the reason for staying. However, a stay has to be defined precisely, i.e. verbalised as a 'story' (narration in place) relating to a certain area, i.e. 'shared territory', as well as route that allows us to learn consecutive parts, the so-called route that shares a village's values (see NiEDźwIEDZKA-FILIPIAK \& WILCZYŃSKI 2015, p. 12). The narration of a place is routinised down to a specific route and time that is needed to learn or elicit experiences and emotions.

\section{Research results}

Positive evaluation, and thus a confirmation of adequate conditions for participating in the network (SNW) was only possible if a village scored at least 35 points out of 100 with no evaluation at the disqualifying level. 46 villages out of 50 invited to participate achieved a positive score. Four villages with negative evaluation were: Klisino (Voivodship Opole, 30 points), Wzdół Rządowy (Voivodship Holy Cross, 27.5 points), Złaków Borowy (Voivodship Łódź, 26 points) and Lubcza (Voivodship Holy Cross, 20 points).

It should be emphasised that the results varied widely. The difference between the top-rated village, Istebna (Silesian Voivodship [województwo Śląskie], 79 pts.) and the worst-scored Lubcza amounted to as much as 59 points. The average result of the whole fifty is 51.7 points with a standard deviation of 14.3 points (see Fig. 2). Distribution of the study population according to the mean, "mean + standard deviation" and "mean standard deviation", or four groups, coincided closely with project objectives. The limit value between two best groups (mean + standard deviation), i.e. 66 points, corresponds to the level assumed at the beginning, which is the threshold for village's certification, i.e. joining the network. 
Table 1: Issues and features of village evaluation

\begin{tabular}{|c|c|c|c|c|}
\hline No. & Issue & Detailed issues & Features & $\begin{array}{c}\text { Total number } \\
\text { of points } \\
\text { possible for a } \\
\text { detailed issue }\end{array}$ \\
\hline 1 & $\begin{array}{l}\text { Village } \\
\text { resources } \\
\text { - material base } \\
\text { located in space, } \\
\text { which decides } \\
\text { on village } \\
\text { values. }\end{array}$ & $\begin{array}{l}\text { 1. Spatial } \\
\text { arrangement } \\
\text { and the image } \\
\text { of the village } \\
\text { - the historic } \\
\text { value of objects, } \\
\text { their technical } \\
\text { and visual } \\
\text { condition, } \\
\text { quality and } \\
\text { functionality of } \\
\text { rural space. }\end{array}$ & $\begin{array}{l}\text { 1. Spatial order - landscape profile } \\
\text { 2. Spatial order - overall image } \\
\text { 3. Spatial order - central places } \\
\text { 4. Spatial order - surroundings } \\
\text { 5. Spatial order - entry routes } \\
\text { 6. Monuments, objects, forms in space of } \\
\text { particular historic value - rural arrangement } \\
\text { 7. Monuments, objects, forms in space of } \\
\text { particular historic value - historic buildings } \\
\text { 8. Monuments, objects, forms in space of } \\
\text { particular historic value - distinguishing } \\
\text { features } \\
\text { 9. Monuments, objects, forms in space of } \\
\text { particular historic value - farm buildings } \\
\text { and others of high historic and architectural } \\
\text { value } \\
\text { 10. Buildings and property (architecture, } \\
\text { technical condition, scope and nature of } \\
\text { transformations) - buildings } \\
\text { 11. Buildings and property (architecture, } \\
\text { technical condition, scope and nature of } \\
\text { transformations) - surroundings (yards, } \\
\text { gardens, orchards) } \\
\text { 12. Buildings and property (architecture, } \\
\text { technical condition, scope and nature } \\
\text { of transformations) - fences (condition, } \\
\text { adequacy) } \\
\text { 13. Public space and equipment } \\
\text { 14. Natural and landscape elements, green } \\
\text { areas and types inside the village } \\
\text { 15. The quality of the environment and } \\
\text { relationship with the environment - the } \\
\text { landscape frame of a village visible from } \\
\text { within } \\
\text { 16. The quality of the environment and } \\
\text { relationship with the environment - } \\
\text { viewpoints giving an insight into the } \\
\text { environment } \\
\text { 17. The quality of the environment and } \\
\text { relationship with the environment - valuable } \\
\text { natural and landscape elements in direct } \\
\text { vicinity of the village }\end{array}$ & 30 \\
\hline
\end{tabular}




\begin{tabular}{|c|c|c|c|c|}
\hline No. & Issue & Detailed issues & Features & $\begin{array}{l}\text { Total number } \\
\text { of points } \\
\text { possible for a } \\
\text { detailed issue }\end{array}$ \\
\hline 2 & & $\begin{array}{l}\text { 2. Tourist } \\
\text { infrastructure } \\
\text { - facilities that } \\
\text { enable the use } \\
\text { of village's } \\
\text { qualities }\end{array}$ & $\begin{array}{l}\text { 18. Accommodation } \\
\text { 19. Gastronomy } \\
\text { 20. Sites dedicated to visitors (parking, stop, } \\
\text { rest) } \\
\text { 21. Active rest facilities } \\
\text { 22. Connectivity and Internet }\end{array}$ & 20 \\
\hline 3 & & $\begin{array}{l}\text { 3. Value } \\
\text { sharing - } \\
\text { infrastructure } \\
\text { for learning } \\
\text { the value of a } \\
\text { village, form } \\
\text { of sharing } \\
\text { (route and } \\
\text { descriptions) }\end{array}$ & $\begin{array}{l}\text { 23. The course of the route for sharing } \\
\text { village's value - defining attractiveness / } \\
\text { cognitive value of the village } \\
\text { 24. The course of the route for sharing } \\
\text { village's value - visibility of the village's } \\
\text { values } \\
\text { 25. Route start or starts } \\
\text { 26. Resting places for tourists } \\
\text { 27. Moving along the route } \\
\text { 28. Route description system } \\
\text { 29. Other existing routes and tracks }\end{array}$ & 20 \\
\hline 4 & \multicolumn{2}{|c|}{$\begin{array}{l}\text { Village specificity } \\
\text { - a set of elements that } \\
\text { distinguish a village and ensure } \\
\text { its recognisability. The specificity } \\
\text { creates the uniqueness of a place, } \\
\text { its identity and, as a result, its } \\
\text { recognisability. }\end{array}$} & $\begin{array}{l}\text { 30. Defining the reason for stay } \\
\text { 31. Communicating and developing the } \\
\text { specificity/attractiveness - information } \\
\text { resources, website, etc. } \\
\text { 32. Communicating and developing the } \\
\text { specificity - distinguishing features, visual } \\
\text { signage system and others } \\
\text { 33. Communicating and developing the } \\
\text { specificity - services, products, souvenirs } \\
\text { 34. Learning the specificity of a village, } \\
\text { education - cyclical or occasional events } \\
\text { 35. Learning the specificity of a village, } \\
\text { education - artistic activities, workshops, } \\
\text { games }\end{array}$ & 15 \\
\hline 5 & \multicolumn{2}{|c|}{$\begin{array}{l}\text { Impressions (climate) } \\
\text { - a set of conditions that create } \\
\text { experiences, shape imagination } \\
\text { and stimulate senses. Climate } \\
\text { exists in symbolic space described } \\
\text { by the spiritual heritage and } \\
\text { the emotions forming under the } \\
\text { influence of external factors. }\end{array}$} & $\begin{array}{l}\text { 36. Promotion of rural values } \\
\text { 37. The life of a village and its inhabitants, } \\
\text { maintaining tradition and customs } \\
\text { 38. Sensual space } \\
\text { 39. Supra-local impact of attractiveness }\end{array}$ & 15 \\
\hline total & 3 issues & 5 detailed issues & 39 features & 100 \\
\hline
\end{tabular}

Source: based on NiEDźWIEDZKA-FILIPIAK \& WILCZYŃSKI 2015 
Figure 2: Overall result of expert evaluation of 50 villages chosen for the study

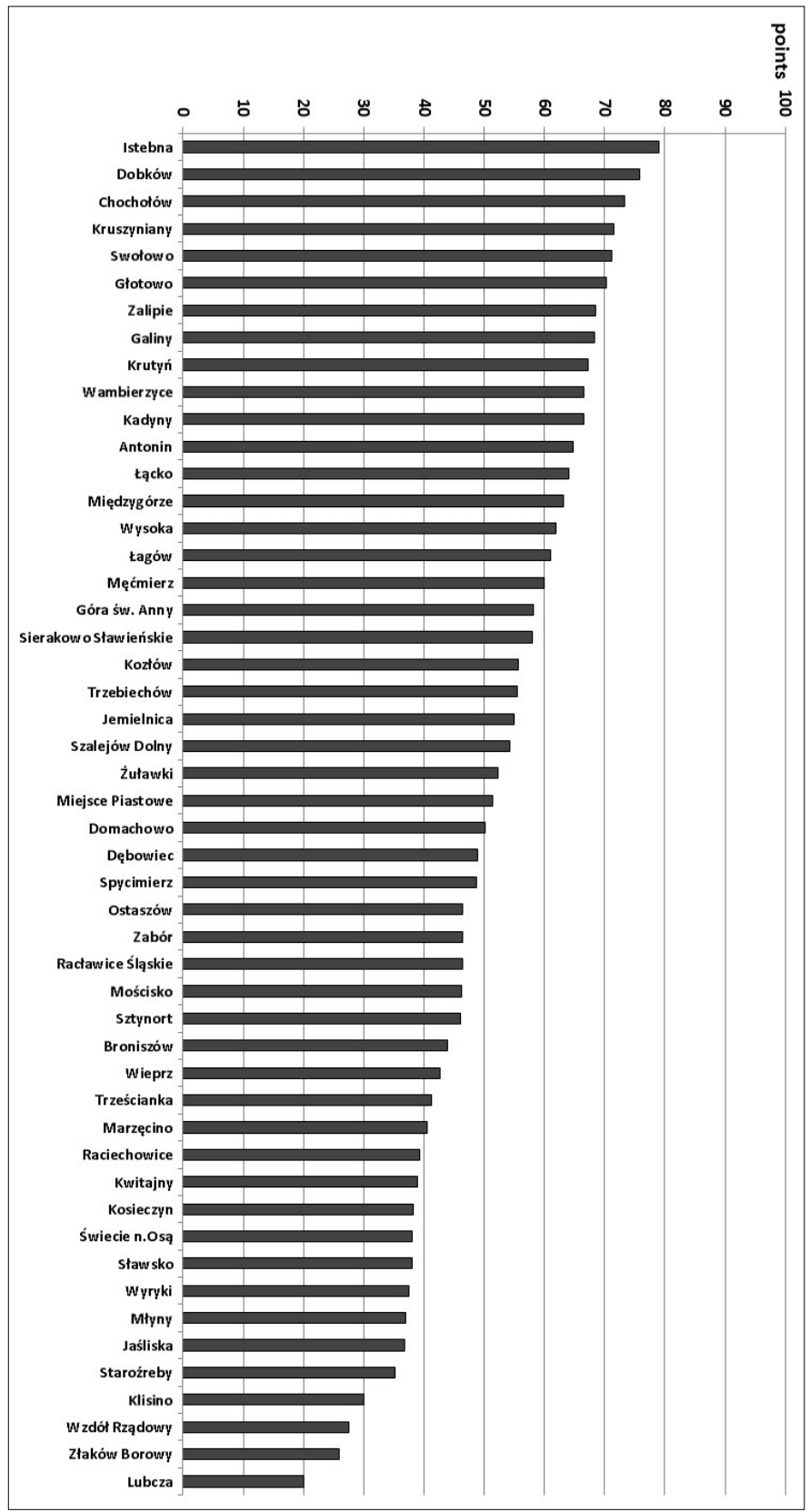

Source: own study 
The limit value between the two lower-scored groups of villages (mean - standard deviation), i.e. 37.4 pts., almost coincides with the assumed level, under which a village was evaluated negatively (35 points).

This relatively even distribution of expert evaluation of 50 villages served as a foundation to develop a classification of five groups with the span of three middle groups of 10 points (Table 2). Thus, the population was divided into groups: with very big (65.0 point and more) and big potential to participate in the network $(55.0-64.99$ points), average potential $(45.0-54.99$ points), small potential $(35.0-44.99)$ and very small potential (below 35 points).

Table 2: Villages participating in the project according to evaluation group

\begin{tabular}{|l|l|l|}
\hline \multicolumn{1}{|c|}{ group } & $\begin{array}{c}\text { number of } \\
\text { villages }\end{array}$ & \multicolumn{1}{|c|}{ villages } \\
\hline up to 35.0 points & 4 & Klisino, Wzdół Rządowy, Złaków Borowy, Lubcza \\
\hline 35.0-44.99 points & 13 & $\begin{array}{l}\text { Broniszów, Wieprz, Trześcianka, Marzęcino, Raciechowice, } \\
\text { Kwitajny, Kosieczyn, Świecie n. Osą, Sławsko, Wyryki, Młyny, } \\
\text { Jaśliska, Staroźreby }\end{array}$ \\
\hline 45.0-54.99 points & 11 & $\begin{array}{l}\text { Szalejów Dolny, Żuławki, Miejsce Piastowe, Domachowo, } \\
\text { Dębowiec, Spycimierz, Ostaszów, Zabór, Racławice Sląskie, } \\
\text { Mościsko, Sztynort }\end{array}$ \\
\hline 55.0-64.99 points & 11 & $\begin{array}{l}\text { Antonin, Lącko, Międzygórze, Wysoka, Łagow, Męćmierz, } \\
\text { Góra św. Anny, Sierakowo Sławieńskie, Kozłów, Trzebiechów, } \\
\text { Jemielnica }\end{array}$ \\
\hline 65.0 or above & 11 & $\begin{array}{l}\text { Istebna, Dobków, Chochołów, Kruszyniany, Swołowo, Głotowo, } \\
\text { Zalipie, Galiny, Krutyń, Wambierzyce, Kadyny }\end{array}$ \\
\hline
\end{tabular}

Source: own study

Spatial distribution of villages in individual groups allows us to show the following regularities (Fig. 3). It turns out that there is a relationship between village location (region) and its evaluation level. Relatively higher scores were awarded to villages in voivodships that have the best-preserved cultural heritage, i.e. Lower Silesia, Lubusz, Opole, Western Pomerania and Warmia-Masuria. Villages with very high and high potential to participate in the Network of the Most Interesting Villages are grouped spatially - perspective clusters, which may facilitate their further presence in the tourism market (exchanging experiences, common problems, possible development financing from the same sources). In the remaining regions, high scores among candidates are exceptions standing out owing mainly to their awareness of their own value and their own, already existing tourist brand, i.e. Kruszyniany, Chochołów, Zalipie, Istebna, Męćmierz. 
Figure 3: Scoring of villages (by group) in the country

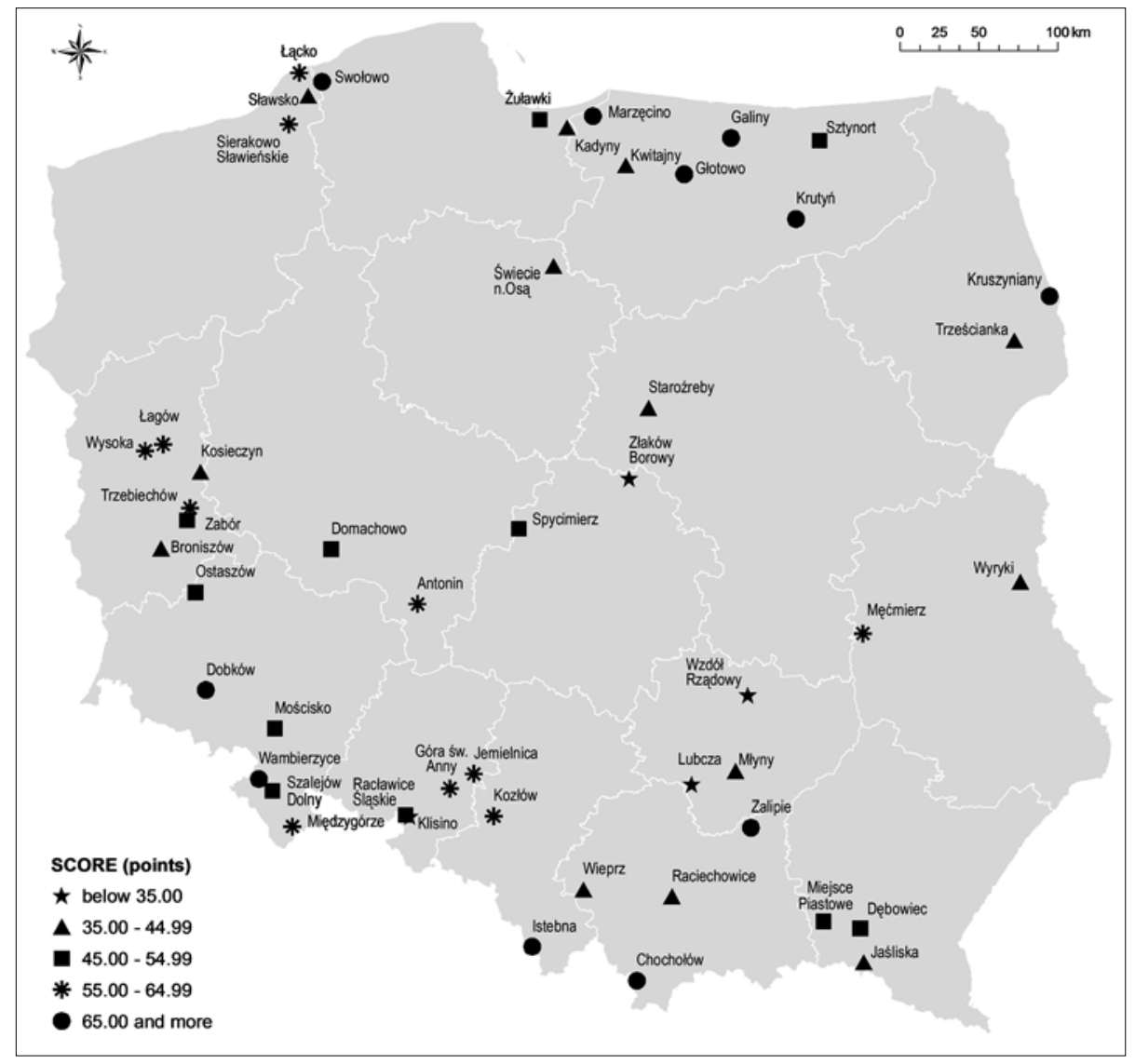

Source: own study

Among the five issues of evaluation, aspects pertaining to the formation and image of the village were scored highest (Fig. 4). Consecutive high positions were occupied by the way the inhabitants propose to share the village's resources and the village's characteristic features, or the set of elements that determine the recognisability of a village and its current offer. The lowest-scored aspects included those related to the presence and operation of accommodation infrastructure, namely all objects and equipment meant to keep the visitors in the village as long as possible, thus building or re-enforcing the economic foundations of the village. It can be concluded that the existing resources and the awareness of their existence are a significant asset in many villages. However, shortages resulting from poor promotion of what is valuable and the lack of a long-lasting relationship with the local environment are now the main barriers that prevent most villages from joining the network. 
Figure 4: Average value of in individual issues of evaluation as compared to the maximum number of points possible $(\%)$

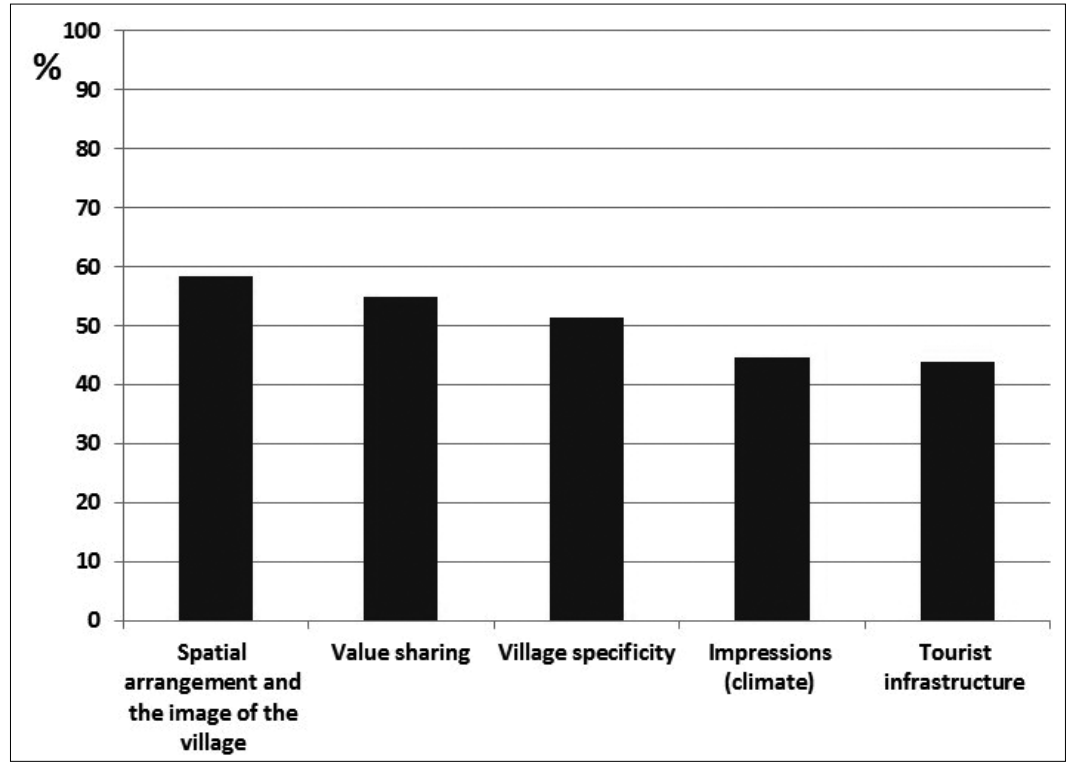

Source: own study

A more precise definition of the features that have been assessed best and worst on average during the study allows us on one hand to show the strengths and weaknesses of rural settlement as far as participation in the Network of the Most Interesting Villages is concerned and, on the other, to point to the key intervention areas that should serve to improve the value of a village. The highest-scored aspects include:

(1) Nature and landscape inside the village: The natural diversity and landscape inside the village were relatively best-scored, which is largely due to the well-preserved and maintained greenery in public areas and its relation to the natural environment surrounding the village. Many villages, owing to their location in naturally attractive regions of Poland (with varied sculpture, forest cover) have diversified physiography, including such elements important for good perception of landscape as rivers, lakes, monadnocks, outcrops and valuable natural areas.

(2) Distinguishing features of the village: Each village has its own character, an effect of complex natural and cultural conditions (both regional and local). Most villages have great potential to distinguish and highlight the elements that will be uniquely theirs as compared to other participants of the network and the rural settlement network in the whole country. 
Figure 5: Swołowo - an example of a candidate with high values based on preserved material cultural heritage

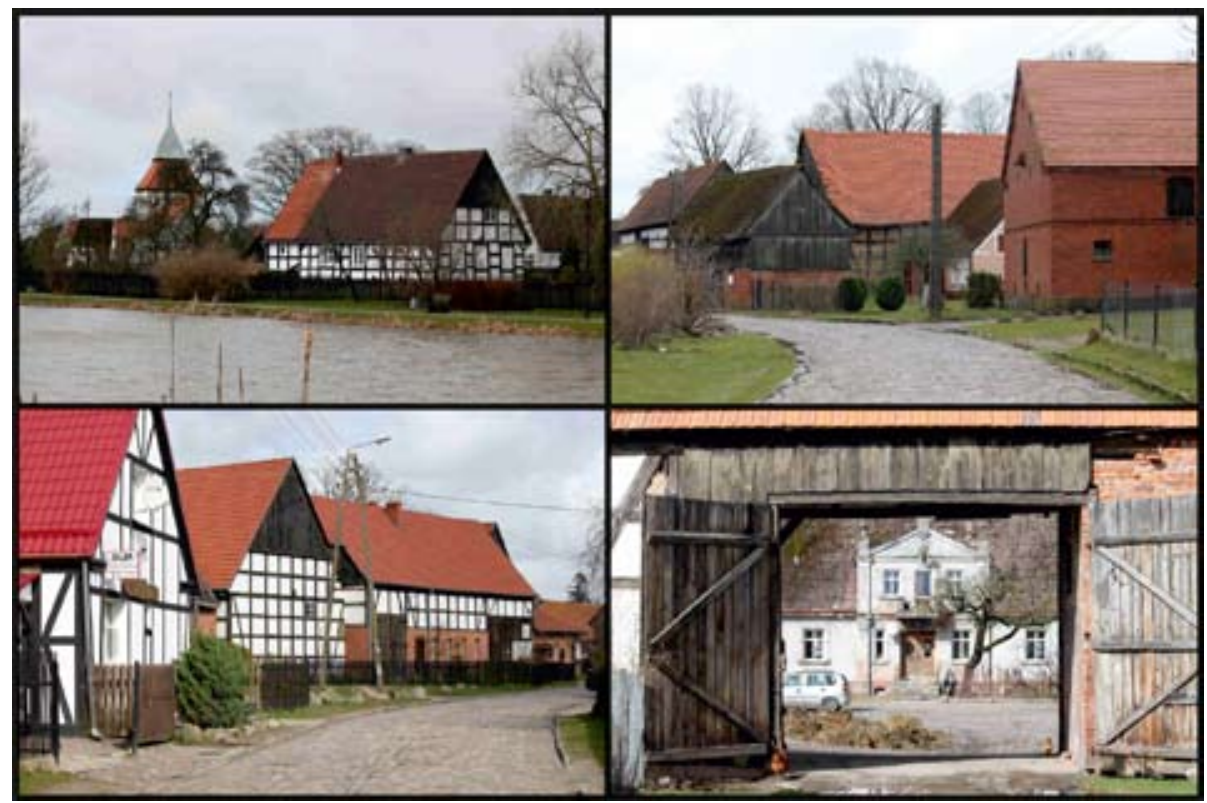

Photo: Marcin WóJcIK

(3) Entrance routes: Most villages have compact settlement systems and are clearly separate from other villages, so well-formed routes are an important landscape feature, that are usually dictated by old trees growing along the roads, fields and the terrain.

(4) Historic structures: The selection of villages to be assessed assumed that the material cultural heritage plays an important role in creating the brand of most villages. Villages were characterised by the variety of architectural and landscape forms, i.e. sacred, residential, farming, public utility structures, as well as small architecture.

(5) Surrounding nature and landscape: Most villages are located in regional peripheries, so the degree of landscape transformation is low (suburbanisation, industrialisation, communication investments, etc.). Also, most villages are located in touristically attractive landscape zones (belts) - seaside, lakes, mountains. 
Figure 6: Sierakowo Stawieńskie - an example of a candidate with high values based on non-material features ("experiences and emotions")

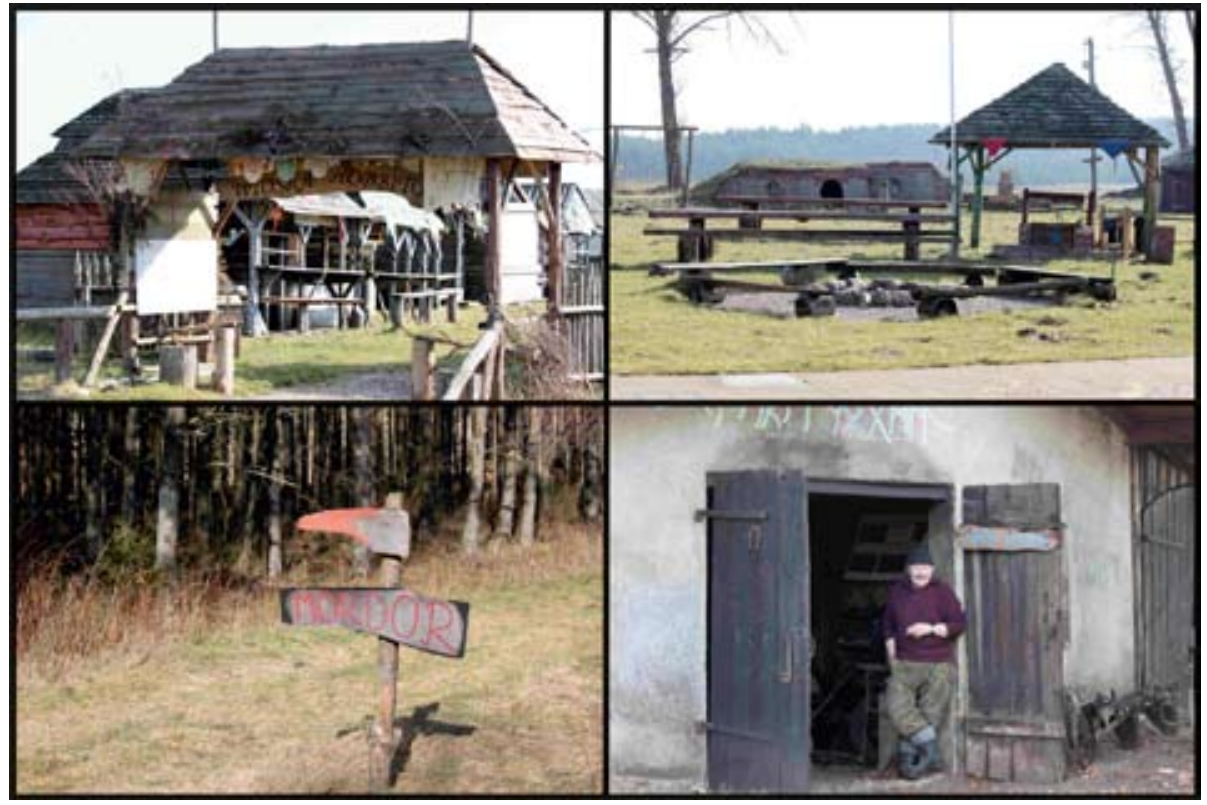

Photo: Marcin WóJciK

(6) Spatial arrangement: Villages represent different morphogenetic layouts, most frequently compact, with many villages representing old settlement forms such as multistreet villages, oval villages, linear villages, serial and parallel villages. These forms are frequently characterised by good or very good preservation of the original layout.

(7) Landscape frame (panorama and view axes): Varied terrain and the interior of the village often unspoiled by new buildings allow for observing the surrounding landscape (from special viewpoints or through 'windows' in the settlement), as well as along the axes of the village.

The following aspects were scored the lowest:

(1) The condition of fences: One of the most dissonant elements in rural landscapes. The inadequacy of this element relative to the objects valuable in terms of cultural and natural heritage, a very large diversity of materials and aesthetic and the internal inconsistency are the greatest factor in lowering the attractiveness of a village. 
(2) The technical condition of buildings: In most villages the technical condition of buildings can translate in the next few years into the loss of key cultural assets. Another threat is posed by makeshift repairs, the destruction of architectural details and the lack of public understanding for the worth of certain structures, especially farming-related ones.

(3) Services, products, souvenirs: Most villages do not promote their individuality through the sale of even small souvenirs, products resulting from highlighting the nature of the place.

(4) Route description: Villages very rarely provide full information on moving around the area, as well as about valuable objects or important events.

(5) Places for tourists: Lack of locations dedicated to tourists is one of the biggest obstacles to keeping the tourists longer and sparking their passion for learning, as well as reflections over the place they are visiting.

(6) Visual information system: There is usually no information that would create a narration for a given place and use the symbolism created for original places and routes.

(7) Surrounding of buildings: The surrounding of buildings is usually inconsistent with their character, which results in makeshift expansions, disorder around buildings and replacing the traditional rural leafy vegetation with coniferous plants.

The evaluation, as well as the analysis of the material collected in this regard allows us to conclude that there is vast regional variability in the resources of rural cultural heritage, both in terms of their architectural and physiognomic types and the condition of their preservation. In this respect, mostly villages in areas joined by Poland in 1945 (Warmia-Masuria, Lubusz, Lower Silesia, Opole, Western Pomerania voivodships) are predisposed to be included in the network. The degree to which rural material heritage has been preserved stems to a large extent from the variability in construction materials and the standard of the objects. This was most negatively reflected in the state of preservation of cultural heritage in central Poland (Łódź, Masovia, KuyavianPomeranian, Holy Cross voivodships), where the model of post-war transformation had led to total destruction of wooden constructions that can now only be seen in open-air museums. Complexes of objects with more durable construction (stone, brick, daub) and higher standard of residence, mostly taken over from displaced German communities, are now the main basis for finding villages to be included in the network. Their potential in this regard is much higher, although the degradation of resources is high in many cases. 


\section{Discussion}

We should view the regional peripheries where most villages with high potential of entering the network are located as an area fit for innovative operations that may increase their social and economic level. Rural peripheral areas include many resources that, if appropriate instruments are used, can be turned into places of leisure, residence and, owing to new technologies, of work. Villages with sufficiently high potential for participation in the network may become centres of social and economic development in the future.

The most pressing issue for the development of villages under evaluation is the preservation of resources, especially valuable rural systems (layouts and objects) in a condition that would allow their proper exhibition and aesthetic perception. The degradation of valuable buildings, especially those owned privately (such as farming buildings), is very high and only few villages can boast that their objects are well-maintained. The renewal processes and, often, even basic protection against destruction, is not helped by low social awareness of their historical worth and lack of responsibility for passing this heritage to future generations. For many villages with unique architecture and layouts, the next 15-20 years will be key, as this is when the final destruction of basic resources may happen, resources that are now still significant in attracting interest in the village from rural development and renewal institutions, as well as from enthusiasts of historical heritage.

One feature that reduces the potential for nearly all evaluated villages is the low aesthetics of fences, especially in private properties. At this stage in rural landscape transformation, fences around properties are the least original (coherent) element of rural equipment. Most of them are cheap substitutes for what should be complementary ingredients of the architectural and physiognomic environment.

One important factor in modern transformation of villages with high potential of being included in the network is the social activity of their inhabitants, that may be interpreted as signs of 'new' rurality related to the fact that many rural areas are now entering the post-production stage in their development. The main feature of this 'new' rurality is that a village is treated as an alternative place of residence and work to the urban one, which shows the growing awareness of the value of rural areas. This applies to both new residents fascinated by the genuine rural heritage and the opportunities coming from its creative development, as well as some native inhabitants that exhibit growing interest in their own identity, combined with the opportunities to gain measurable profits from servicing tourists and social groups that seek new cultural experiences and are sensitive to stimuli coming from the rural 'milieu'.

The recipe for success includes many elements that need to be noticed and appreciated. The most important ones include attractive spatial organisation, which does not lack central locations that focus cognitive and recreational functions; the social awareness of the worth of one's own heritage and the ability to talk about it 
(specifying the reason for staying); the existence of long-lasting institutions that refer to historical memory and communal activities; the ability to create media for the narration located in the internal environment; a somewhat formed path for one's own development based on one's own resources (developed tourism functions); as well as operation within a local a regional network of villages of various functions and values of natural and anthropogenic environment (tourist regions).

One extremely important factor in the development of interesting villages and their participation in the network is the help and support from local governments that are responsible for launching various promotional, institutional and legal instruments. The political and administrative instability, as well as the lack of long-term vision for development, including short-term high expectations, may weaken the network membership (e.g. the loss of key resources, decreasing local community's activity, internal competition). Apart from the characteristics common to all members (a typical set of features that enable success), each village with high potential for participating in the network has their own original developmental conditions, including unique resources and only the local social environment, namely decision makers, leaders, communities can perceive them, understand them and properly promote them to the recipient.

\section{References}

Biczkowski M. (2013), Przestrzenna alokacja wsparcia finansowego z instrumentów wspólnej polityki rolnej i ich wpływ na rozwój społeczno-gospodarczy obszarów wiejskich. In: Folia Geographica Socio-Oeconomica, 13, pp. 93-114.

BuKRABA-RYLSKA (1992), Badanie kultury a odbudowa tożsamości wsi współczesnej. In: WieruszewsKa M. (ed.), Odnowa wsi. Między mitem a nadzieją, pp. 133-157. Warszawa, IRWiR PAN.

GILG A. (1998), Policies and planning mechanisms: managing change in rural areas. In: ILBERY B. (ed.), The geography of rural change, pp. 189-210. Harlow, Pearson.

Grabski U. (1989), Ökologie und Dorfentwicklung. In: Geographische Rundschau, 3, pp. $163-$ 168.

HeinRitz G., Wiesser R. (eds.) (1997), Dorfbewohner als Dorfentwickler (= Münchener Geographische Hefte, 75). Passau, Passavia Universitätsverlag.

Henkel G. (2004), Der ländliche Raum. Berlin - Stuttgart, Gebrüder Borntraeger Verlagsbuchhandlug.

IDZIAK W., WilcZYŃSki R. (2013), Odnowa wsi. Przestrzeń, ludzie, działania. Warszawa, FAPA.

KŁodZIŃSKI M., BŁĄD M., WiLCZYŃSKi R. (eds.) (2007), Odnowa wsi w integrującej się Europie. Warszawa, IRWiR PAN.

Lienau C. (1989), Geographie der ländlichen Siedlungen. In: Geographische Rundschau, 3, pp. 134-141. 
Millendorfer J. (1990), Werte- und Paradigmenwandel macht den ländlichen Raum zum Ort der Zukunft. In: GlüCK A., Magel H. (eds.), Das Land hat Zukunft. Neue Perspektiven für die ländlichen Räume, pp. 27-33. München, Kommunalschriften-Verlag J.Jehle.

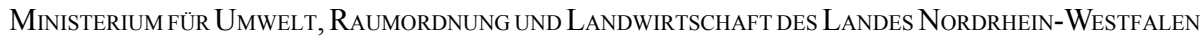
(ed.) (1998), Modellprojekt Ökologisches Dorf der Zukunft, Schlussdokumentation und Auswertung. Düsseldorf.

NiEDŹWIEDZKA-FILIPIAK I. (2009), Wyróżniki krajobrazu i architektury wsi Polski południowozachodniej. Wrocław, University of Life Sciences.

NiedźwIEdZKa-FiLIPIAK I., WiLcZyŃSKi R. (2015), Walory miejscowości - tworzywem Sieci Najciekawszych Wsi. Opole, Office of the Marshall of Opole.

Planck U. (1986), Dorferneuerung und Dorfforschung. Beitrag und Methoden der Soziologie (= Schriftenreihe für Agrarpolitik und Agrarsoziologie, 42). Graz - Linz, Österr. Inst. f. Agrarpolitik u. Agrarsoziologie, Stocker.

Psyk-Piotrowska E., Zajda K., Kretek-Kamińska A., WalcZaK-Duraj D. (2013), Struktura i uwarunkowania kapitału społecznego lokalnych grup działania. Łódź, University of Łódź.

RudNicki R. (2010), Zróżnicowanie przestrzenne wykorzystania funduszy Unii Europejskiej przez gospodarstwa rolne w Polsce. Poznań, Bogucki Wydawnictwo Naukowe.

WILCZYŃSKI R. (2012a), Odnowa wsi z wykorzystaniem środków europejskich - niewykorzystana szansa na rewitalizację. In: Architektura Krajobrazu, Studia i Prezentacje, 2, 35, pp. 4-22.

WILCZYŃSKI R. (ed.) (2012b), Sieć Najpiękniejszych Wsi. Opracowanie eksperckie projektu. Opole, PROW, KSOW.

Wóscik M. (2010), Struktura i działanie - geograficzno-społeczna interpretacja oddziaływania funduszy Unii Europejskiej na przykładzie programu „Odnowa wsi”. In: KACPRZAK E., KoŁodziejczAK A. (eds.), Rola środków Unii Europejskiej w rozwoju obszarów wiejskich (= Studia Obszarów Wiejskich, 24), pp. 186-201. Warszawa, Rural Research Team of the Institute of Geography and Spatial Organisation, Polish Academy of Sciences, Committee for Rural Areas, Polish Geographical Society.

WóJcik M. (2012), Geografia wsi w Polsce. Studium zmiany podstaw teoretycznometodologicznych. Łódź, University of Łódź.

Woods M. (2005), Rural geography. London, Sage. 